\title{
R. Revista

\section{Symbiotic effectiveness of Bradyrhizobium ingae in promoting growth of Inga edulis Mart. seedlings}

\author{
Dilacy Sales Porto ${ }^{(1)}$, Eliane do Nascimento Cunha Farias ${ }^{(2)}$, Josimar da Silva Chaves ${ }^{(3)}$, \\ Brenda Ferreira Souza ${ }^{(4)}$, Roberto Dantas de Medeiros ${ }^{(2)}$, Jerri Édson Zilli ${ }^{(5)}$ and Krisle \\ da Silva ${ }^{(2)^{*}}$ \\ (1) Universidade Estadual de Roraima, Pró-Reitoria de Pesquisa, Pós-Graduação em Agroecologia, Boa Vista, \\ Roraima, Brasil. \\ (2) Empresa Brasileira de Pesquisa Agropecuária, Embrapa Roraima, Boa Vista, Roraima, Brasil. \\ (3) Universidade Federal de Roraima, Departamento de Agronomia, Pós-Graduação em Agronomia, Campus \\ Cauamé, Boa Vista, Roraima, Brasil. \\ ${ }^{(4)}$ Instituto Federal de Educação, Ciência e Tecnologia de Roraima, Boa Vista, Roraima, Brasil. \\ ${ }^{(5)}$ Empresa Brasileira de Pesquisa Agropecuária, Embrapa Agrobiologia, Seropédica, Rio de Janeiro, Brasil.
}

* Corresponding author:

E-mail: krisle.silva@embrapa.br

Received: April 25, 2016

Approved: August 29, 2016

How to cite: Porto DS, Farias ENC, Chaves JS, Souza BF, Medeiros RD, Zilli JE, Silva K. Symbiotic effectiveness of Bradyrhizobium ingae in promoting growth of Inga edulis Mart. seedlings. Rev Bras Cienc Solo. 2017;41:e0160222.

Copyright: This is an open-access article distributed under the terms of the Creative Commons Attribution License, which permits unrestricted use, distribution, and reproduction in any medium, provided that the original author and source are credited.
ABSTRACT: Inga edulis Mart. is a leguminous tree adapted to acidic and low-fertility soils that establishes symbioses with nitrogen (N)-fixing bacteria. The identification of effective bacteria in biological $\mathrm{N}$ fixation may bolster the use of $\mathrm{I}$. edulis in degraded or modified areas and agroforestry systems. Therefore, the aims of this study were evaluation of the symbiotic effectiveness of eight strains of the Bradyrhizobium genus native to Roraima in Inga edulis plants, and in vitro evaluation of the ability of the eight strains of Bradyrhizobium to develop plant growth-promoting characteristics. Determination of symbiotic effectiveness was carried out via three experiments: the first in a greenhouse in pots with a sterile substrate; the second in a greenhouse in pots containing non-sterile soil; and the third in a nursery in bags with a non-sterile substrate. Twelve treatments were evaluated: inoculation with eight strains of Bradyrhizobium ingae (ERR 490, ERR 492, ERR 493, ERR 494 ${ }^{\top}$, ERR 496, ERR 497, ERR 498, and ERR 569); inoculation with two strains indicated for Inga marginata, BR 6609 and BR 6610 (positive controls); no inoculation but with mineral N; and neither inoculation nor mineral $\mathrm{N}$. All of the experiments were conducted in a completely randomized design with four replicates. The first experiment was conducted for 60 days, and the other experiments were conducted for 100 days. For all of the experiments, the number of nodules, nodule dry matter, root dry matter, shoot dry matter, number of leaflets, plant height, stem diameter, total $\mathrm{N}$ in the shoots, root/shoot dry matter ratio, Dickson's quality index, relative effectiveness, and the Pearson correlation between the variables under study were evaluated. The strains were also evaluated by their ability to solubilize calcium and aluminum phosphates and to produce indolic compounds. The results showed that $B$. ingae strains were effective in biological $N$ fixation, especially the ERR 493, ERR 498, and ERR 569 strains. These strains increased the production of shoot dry matter and total $\mathrm{N}$ and exhibited relative effectiveness higher than $100 \%$ in all of the experiments. The $B$. ingae strains were also able to solubilize calcium and aluminum phosphates, despite their synthesis of indolic compounds. Thus, the strains of $B$. ingae can be used for inoculation in the production of $I$. edulis seedlings.

Keywords: biological nitrogen fixation, phosphate solubilization, indolic compounds. 


\section{INTRODUCTION}

Species of the Inga genus are leguminous trees belonging to the Leguminosae family and Mimosoideae subfamily, which includes approximately 300 species in neotropical regions (Pennington, 1997); 131 of these species occur in Brazil (Garcia and Fernandes, 2015). Inga spp. have the potential for use in low-nitrogen (N) input agriculture because they establish symbioses with $\mathrm{N}$-fixing bacteria, yield high biomass, and are tolerant of acidic soils (Hands, 1998).

Inga edulis Mart. is a species that has been used by Latin American farmers aiming to provide shade for coffee (Coffea arabica L.) and cacao (Theobroma cacao L.) plants (Leblanc et al., 2006). This leguminous plant is also commonly intercropped with Terminalia amazonia (J. F. Gmel.) Excell in degraded areas with the goal of promoting the development of this timber species (Nichols et al., 2001). The symbiotic effectiveness between $\mathrm{N}$-fixing bacteria and leguminous trees is critical for improving sustainable production systems. For example, plants that establish symbiosis with $\mathrm{N}$-fixing bacteria such as Inga spp. are extremely important for organic coffee cultivation systems in Mexico, where the application of $\mathrm{N}$ via chemical fertilizers is not allowed (Grossman et al., 2006).

Inga edulis occurs in diverse phytogeographical domains in Brazil, including the Amazon, Caatinga, Cerrado, and Atlantic Forest (Possette and Rodrigues, 2010; Souza et al., 2011; Garcia and Fernandes, 2015). Despite its wide occurrence and its potential for use in agroforestry systems and in recovery of degraded or altered areas, there are no bacterial strains recommended for these leguminous plants. Studies in this field can lead to the selection of effective $\mathrm{N}$-fixing bacteria, thereby increasing $\mathrm{N}$ input in more sustainable systems, resulting in increased soil fertility. In Brazil, there are only two bacterial strains currently recommended for inoculation of the I. marginata species (Franco and Faria, 1997; Brasil, 2011). Therefore, it is necessary to select strains for other Inga species.

Recently, strains of N-fixing bacteria were isolated from Inga laurina (Sw.) Willd. nodules collected in the state of Roraima, Brazil. These strains were characterized and described as a new Bradyrhizobium species named B. ingae (Silva et al., 2014). Although these strains were capable of nodulating $I$. edulis, their symbiotic effectiveness was not evaluated. In addition to capacity for $\mathrm{N}$ fixation in these bacterial strains, it is necessary to identify other important processes in them that could promote plant growth, including phytohormone production and phosphate solubilization (Antoun et al., 1998; Boiero et al., 2007; Kuss et al., 2007; Oliveira-Longatti et al., 2014). Therefore, the main hypothesis of our study was that $B$. ingae strains isolated from I. laurina in Roraima are effective in biological $\mathrm{N}$ fixation and can be used for $\mathrm{I}$. edulis seedling production. In addition, another hypothesis is that $B$. ingae strains have mechanisms for promoting plant growth, such as the ability to solubilize phosphates and produce phytohormones. Along with biological $\mathrm{N}$ fixation, these growth-promoting mechanisms could aid the development of $I$. edulis seedlings and other plant species.

The objectives of this study were to evaluate the symbiotic effectiveness of eight $B$. ingae strains native to Roraima in $I$. edulis plants and to evaluate the ability of these strains to develop characteristics for promoting plant growth in vitro.

\section{MATERIALS AND METHODS}

\section{Origin of strains}

The bacterial strains used in this study were isolated from I. laurina (Sw.) Willd. nodules collected under natural savannah conditions in the state of Roraima at the Monte Cristo Experimental Station that belongs to Embrapa Roraima and in an area within the city of Boa Vista. The geographic coordinates of these sampling areas were $2^{\circ} 50^{\prime} 21^{\prime \prime} \mathrm{N}$, $60^{\circ} 40^{\prime} 32,25^{\prime \prime} \mathrm{W}$ and $2^{\circ} 57^{\prime} 00^{\prime \prime} \mathrm{N}, 60^{\circ} 42^{\prime} 25^{\prime \prime} \mathrm{W}$, respectively. 
These strains were genotypically and biochemically identified as a new species named B. ingae (Silva et al., 2014). The strains described included ERR 490, ERR 492, ERR 493, ERR 494' ${ }^{\top}$, ERR 496, ERR 497, ERR 498, and ERR 569. Although such strains were isolated from I. laurina plants, they were capable of nodulating I. edulis Mart. However, their symbiotic effectiveness was not evaluated.

\section{Treatments used in the symbiotic effectiveness experiments}

The following twelve treatments were used in the symbiotic effectiveness experiments: inoculation with eight strains of $B$. ingae (ERR 490, ERR 492, ERR 493, ERR 494' ${ }^{\top}$ ERR 496, ERR 497, ERR 498, and ERR 569); inoculation with two strains of Bradyrhizobium spp. recommended in Brazil by the Ministry of Agriculture, Livestock and Food Supply (Ministério de Agricultura, Pecuária e Abastecimento - MAPA) for I. marginata (BR 6609 and BR 6610); no inoculation or added mineral N (Control -N); and no inoculation but with added mineral $\mathrm{N}$ (10 $\mathrm{mg}$ of $\mathrm{N}$ per plant was added weekly in the form of ammonium nitrate) (Control $+N)$. A completely randomized design was used for all of the experiments, with four replicates, for a total of 48 plots per experiment.

Symbiotic effectiveness was evaluated in three experiments: in pots with a sterile substrate in a greenhouse; in pots containing non-sterile soil in a greenhouse; and in bags with non-sterile soil in a nursery.

Inga edulis seeds collected at the Água Boa Experimental Station of Embrapa Roraima were used for all the experiments. This experimental station is located in Boa Vista, Roraima, Brazil, at the coordinates $02^{\circ} 39^{\prime} 00^{\prime \prime} \mathrm{N}$ and $60^{\circ} 49^{\prime} 40^{\prime \prime} \mathrm{W}$. The seeds were disinfected with $92 \%$ ethyl alcohol for $30 \mathrm{~s}$, followed by $2 \%$ sodium hypochlorite for $1 \mathrm{~min}$, and then washed six times with sterile distilled water.

The strains were cultured in liquid medium 79 (pH 6.8) (Fred and Waskman, 1928) and incubated with shaking at $28{ }^{\circ} \mathrm{C}$ for $72 \mathrm{~h}$. The optical density (OD) was adjusted to 0.8 at $630 \mathrm{~nm}$, which represented approximately $10^{8}$ cells $\mathrm{mL}^{-1}$. One milliliter of bacterial culture was used to inoculate each plant 15 days after emergence.

\section{Experiment 1 - Symbiotic effectiveness in sterile substrate in a greenhouse}

The first experiment was conducted in a greenhouse under controlled temperature $\left(28^{\circ} \mathrm{C}\right)$ and light (50\% shade) in Leonard pots (Vincent, 1970). A 2:1 mixture of medium texture sand and vermiculite was used in the top part of the pots as substrate. In the bottom part, Hoagland's nutrient solution ( $\mathrm{pH} \mathrm{7.0)}$ was used (Hoagland and Arnon, 1950) as modified by Guimarães et al. (2012) with low N concentration (5.25 $\mathrm{mg} \mathrm{L}^{-1}$ ). The pots were autoclaved $\left(120{ }^{\circ} \mathrm{C}, 128 \mathrm{~atm}\right)$ twice for $1 \mathrm{~h}$ each time. One seed inoculated with $1 \mathrm{~mL}$ of bacterial medium was planted in each pot. Each pot received $800 \mathrm{~mL}$ of nutrient solution per week; a 4-fold dilution was used for 30 days, and a 2-fold dilution was used for the remainder of the experiment (60 days). The Control $+\mathrm{N}$ treatment received $10 \mathrm{mg}$ of $\mathrm{N}$ per plot per week in the form of ammonium nitrate.

\section{Experiment 2 - Symbiotic effectiveness in non-sterile soil in a greenhouse}

The second experiment was conducted in a greenhouse using polyethylene pots with $2.41 \mathrm{dm}^{3}$ capacities. These pots contained non-sterile soil and washed medium-texture sand in a 1:1 ratio. A Latossolo Amarelo Distrófico (Oxisol) was collected from the $0.00-0.20 \mathrm{~m}$ layer of the Embrapa Roraima station at the coordinates $02^{\circ} 42^{\prime} 30^{\prime \prime} \mathrm{N}$ and $47^{\circ} 38^{\prime} 00^{\prime \prime} \mathrm{W}$. The soil used in the experiment had the following chemical properties: $\mathrm{pH}\left(\mathrm{H}_{2} \mathrm{O}\right)$ of 5.2; $5.0 \mathrm{~g} \mathrm{~kg}^{-1}$ of organic matter; $12 \mathrm{mg} \mathrm{dm}^{-3}$ of $\mathrm{P} ; 0.05 \mathrm{cmol}_{\mathrm{c}} \mathrm{dm}^{-3}$ of $\mathrm{K}^{+} ; 0.7 \mathrm{cmol}_{\mathrm{c}} \mathrm{dm}^{-3}$ of $\mathrm{Ca}^{2+} ; 0.7 \mathrm{cmol}_{\mathrm{c}} \mathrm{dm}^{-3}$ of $\mathrm{Mg}^{2+} ; 1.8 \mathrm{cmol}_{\mathrm{c}} \mathrm{dm}^{-3}$ of $\mathrm{H}+\mathrm{Al}$; and $0.1 \mathrm{cmol}_{\mathrm{c}} \mathrm{dm}^{-3}$ of $\mathrm{Al}^{3+}$.

Two seeds were planted per pot. Plants were thinned after germination to maintain one plant per pot. Pots were irrigated with $100 \mathrm{~mL}$ of distilled water as necessary to maintain adequate soil moisture. 
The experiment was irrigated with sterile Hoagland and Arnon (1950) nutrient solution as modified by Guimarães et al. (2012). For each treatment, a total of $100 \mathrm{~mL}$ per week of nutrient solution was applied per pot; for the first 30 days a 4-fold dilution was applied, followed by a 2-fold dilution for another 30 days, and an undiluted solution until the end of the experiment. The experiment was conducted for 100 days.

\section{Experiment 3 - Symbiotic effectiveness in non-sterile substrate in a nursery}

The third experiment was conducted under nursery conditions, using $3 \mathrm{~L}$ polyethylene bags. A mixture (1:1:1) of soil with clay texture (Latossolo Vermelho-Amarelo), soil with sandy texture (Latossolo Amarelo), and a coarse texture sand was used. The Latossolo Vermelho-Amarelo and the Latossolo Amarelo, both classified as Oxisol, were collected at the Monte Cristo and Água Boa experimental stations of Embrapa Roraima, respectively. After mixing the soils, this substrate had the following chemical properties: $\mathrm{pH}\left(\mathrm{H}_{2} \mathrm{O}\right)$ of 5.9; $6.7 \mathrm{~g} \mathrm{~kg}^{-1}$ of organic matter; $2.57 \mathrm{mg} \mathrm{dm}^{-3}$ of $\mathrm{P} ; 0.04 \mathrm{cmol}_{\mathrm{c}} \mathrm{dm}^{-3}$ of $\mathrm{K}^{+} ; 0.5 \mathrm{cmol}_{\mathrm{c}} \mathrm{dm}^{-3}$ of $\mathrm{Ca}^{2+}, 0.17 \mathrm{cmol}_{\mathrm{c}} \mathrm{mg}^{-3}$ of $\mathrm{Mg}^{2+} ; 1.7 \mathrm{cmol}_{\mathrm{c}} \mathrm{dm}^{-3}$ of $\mathrm{H}+\mathrm{Al}$; and $0.08 \mathrm{cmol}_{\mathrm{c}} \mathrm{dm}^{-3}$ of $\mathrm{Al}^{3+}$.

Two seeds were planted per bag. After thinning, one seed remained in each bag. Irrigation was performed daily using an automated sprinkler system. This experiment was conducted for 100 days. Nutrient solution was applied according to the procedure used for the greenhouse experiment with non-sterile soil.

\section{Variables evaluated and statistical analyses}

One replicate of each treatment was removed to observe nodule formation 45 days after sowing in each experiment. In addition, at the end of each experiment, plants were collected to analyze the following variables: number of nodules (NN); nodule dry matter (NDM); shoot dry matter (SDM); root dry matter (RDM); number of leaflets (NL); plant height (PH); stem diameter (SD); and total $\mathrm{N}$ in the shoots (TN). The RDM/SDM ratio and Dickson's quality index (DQI) (Dickson et al., 1960) were calculated. The latter was calculated using the following equation:

$\mathrm{DQI}=\mathrm{TDM}(\mathrm{g}) / \mathrm{PH}(\mathrm{cm}) / \mathrm{SD}(\mathrm{mm})+\mathrm{SDM}(\mathrm{g}) / \mathrm{RDM}(\mathrm{g})$

where TDM refers to the total dry matter (SDM+RDM). Moreover, relative effectiveness (RE) was determined using the formula RE = inoculated SDM $\times 100 / S D M$ with $N$, where RE is the relative effectiveness, inoculated SDM is the shoot dry matter of plants inoculated with the tested strains and SDM with $\mathrm{N}$ is the shoot dry matter with $\mathrm{N}$ and without inoculation $($ Control $+N)$ (Bergensen et al., 1971). The Shapiro-Wilks normality test at a $5 \%$ significance level was applied to all the variables. The NN, NDM, and NL data did not follow normal distributions and were transformed to $(x+1)^{0.5}$ before analysis of variance. The means were compared using the Scott-Knott test (Scott and Knott, 1974) at a significance level of $5 \%$. Statistical analyses were conducted using R-3.2.2 software (R Core Team, 2013) through the statistical package ExpDes.pt version 1.1.2 (Ferreira et al., 2013).

\section{Pearson's correlation $(r)$}

Pearson's correlation ( $r$ ) was also calculated for the variables analyzed in the three symbiotic effectiveness experiments using R-3.2.2 software.

\section{Phosphate solubilization}

To investigate phosphate solubilization, two experiments were conducted. One experiment aimed to evaluate the ability of the selected strains to solubilize calcium phosphate $\left(\mathrm{CaHPO}_{4}\right)$. The other experiment aimed to check the ability of strains to solubilize aluminum phosphate $\left(\mathrm{AlPO}_{4}\right)$. An NBRIP medium was used (Nautiyal, 1999) with a modified source of phosphate. A total of $2.6 \mathrm{~g}$ of $\mathrm{CaHPO}_{4}$ with $\mathrm{pH}$ adjusted to 7.0 was used for 
the $\mathrm{CaHPO}_{4}$-solubilization experiments. A total of $2.36 \mathrm{~g}$ of $\mathrm{AlPO}_{4}$ with $\mathrm{pH}$ adjusted to 4.5 was used for the $\mathrm{AlPO}_{4}$-solubilization experiments. In solid media, $10 \mathrm{~g}$ of agar per liter was added.

To evaluate the ability of bacterial strains to solubilize calcium and aluminum phosphates in Petri dishes, bacteria were cultured in liquid medium 79 for $72 \mathrm{~h}$, and the OD was adjusted to $0.5-0.7$ at $630 \mathrm{~nm}$. After that, $10 \mu \mathrm{L}$ of bacterial suspension was inoculated at three equidistant points in a Petri dish containing media with precipitated phosphates. The experiment was conducted in a completely randomized design with three replicates. Two strains were included as positive controls for phosphate solubilization: BR11001 ${ }^{\top}$ (Azospirillum brasilense) and BR11175 ${ }^{\top}$ (Herbaspirillum seropedicae). The media with inoculated strains were incubated at $28{ }^{\circ} \mathrm{C}$ for 18 days. Every six days, the diameter of the solubilization halo (translucent areas surrounding the colonies) was measured using a digital caliper (three measurements per colony). A solubilization index (SI) was obtained from these measurements for each strain using the following formula: $\mathrm{SI}=$ halo diameter $(\mathrm{mm}) /$ colony diameter $(\mathrm{mm})$ (Berraquero et al., 1976). Based on the $\mathrm{SI}$, the strains were classified according to their ability to solubilize phosphates as low (SI $<2$ ), medium $(2 \leq \mathrm{SI}<4)$ or high $(\mathrm{SI}>4)$.

To determine the solubilization of insoluble phosphates in liquid media, a $125-\mathrm{mL}$ Erlenmeyer flask containing $30 \mathrm{~mL}$ of NBRIP medium and precipitated $\mathrm{P}$ was inoculated with approximately $1 \mathrm{mg}$ of cells cultured on solid medium 79 . For the medium containing $\mathrm{P}$ precipitated with $\mathrm{Al}, \mathrm{AlPO}_{4}$ corresponding to $12 \mathrm{mg} \mathrm{L}^{-1}$ of $\mathrm{P}$ was used. The experiment was set up as a completely randomized design with three replicates. Two strains were included: BR11001 ${ }^{\top}$ (Azospirillum brasilense) and BR11175 ${ }^{\top}$ (Herbaspirillum seropedicae).

For determining solubilized $\mathrm{P}$, erlenmeyer flasks containing the media inoculated with the selected strains were incubated at $28^{\circ} \mathrm{C}$ under constant shaking at $150 \mathrm{rpm}$ for four days. At the end of this period, the $\mathrm{pH}$ was determined, and the material was centrifuged at $10,000 \mathrm{rpm}$ for $5 \mathrm{~min}$. Next, $5 \mathrm{~mL}$ of the bacterial supernatant was transferred to a $50-\mathrm{mL}$ disposable cup, and $10 \mathrm{~mL}$ of diluted ammonium molybdate solution and approximately $30 \mathrm{mg}$ of ascorbic acid were added to each cup (Embrapa, 2009). After incubation for $1 \mathrm{~h}$, samples were read using an SP2000-UV spectrophotometer at $660 \mathrm{~nm}$. The $P$ concentration was estimated using a standard curve previously prepared with $0,0.1,0.5,0.75,1.0,2.0,3.0,4.0,4.5,5.0$, and $6.0 \mathrm{mg} \mathrm{L}^{-1}$ of $\mathrm{P}$ as $\mathrm{KH}_{2} \mathrm{PO}_{4}$. Statistical analyses of the solubilization experiments were conducted as described in the experiments of effectiveness.

\section{Production of indole compounds}

With the aim of quantifying the production of indoles, $B$. ingae strains were cultured in liquid medium 79 for $72 \mathrm{~h}$, and the OD was adjusted to $0.6-0.8$ at $630 \mathrm{~nm}$. Aliquots of the bacterial suspensions $(500 \mu \mathrm{L}$ ) were inoculated in $6 \mathrm{~mL}$ of medium 79 (without tryptophan, and supplemented with $100 \mathrm{mg} \mathrm{L}^{-1}$ tryptophan) with three replicates. They were then incubated in the dark at $28{ }^{\circ} \mathrm{C}$ for $72 \mathrm{~h}$ under constant agitation at $120 \mathrm{rpm}$.

To quantify the indole compounds produced after this period, cultures were centrifuged at $10,000 \mathrm{rpm}$ for $10 \mathrm{~min}$. Three milliliters of the supernatant were transferred to flasks, and $2 \mathrm{~mL}$ of Salkowski reagent was added (Sarwar and Kremer, 1995). This mixture was kept in the dark for 20 min for color development; an intense pink color is obtained when there are large amounts of indole compounds. Color intensity was determined using a SP2000-UV spectrophotometer at $535 \mathrm{~nm}$. The concentration of indole compounds was estimated using a standard curve previously prepared with an uninoculated sterile culture medium and known quantities of indole acetic acid (IAA), $0,10,25,50,75$, and $100 \mu \mathrm{g} \mathrm{AlA} \mathrm{mL}{ }^{-1}$ (Sigma Aldrich, 13750). Statistical analysis of the production of indolic compounds was conducted as previously described in the symbiotic effectiveness section. 


\section{RESULTS}

\section{Experiment 1 - Symbiotic effectiveness in sterile substrate in a greenhouse}

In the first experiment in sterile substrate, all of the $B$. ingae strains induced the formation of more than 200 nodules per plant (Table 1 ) and there were no significant differences between the strains recommended for I. marginata (BR 6609 and BR 6610). With respect to NDM, treatments ERR 490 and ERR $494^{\top}$ did not differ from BR 6609; however, these two treatments produced significantly higher NDM than the other treatments. There were no significant differences for RDM and NL. For treatments inoculated with ERR 492, ERR 493, ERR 494', ERR 496, and ERR 569 strains, PH was significantly higher than in the other treatments (Table 1). SD was significantly higher in four strains, ERR 492, ERR 493, ERR 494', and ERR 569. For SDM, with the exception of ERR496 and ERR 497, all of the $B$. ingae strains showed significant differences compared to the recommended strains (BR 6609 and BR 6610) and the Controls $-\mathrm{N}$ and $+\mathrm{N}$. For the TN variable, the Control $-\mathrm{N}$ was significantly lower than the other treatments. The RDM/SDM ratio (Figure $1 \mathrm{a}$ ) was significantly higher in the Control $-\mathrm{N}$ treatment than in the other treatments. There were no significant differences in the DQI among the treatments (Figure 1a). A total of seven strains (ERR 490, ERR 492, ERR 493, ERR 494', ERR 496, ERR 498, and ERR 569) had RE values higher than $100 \%$ (Figure 2).

\section{Experiment 2 - Symbiotic effectiveness in non-sterile soil in a greenhouse}

In the second experiment conducted in a greenhouse, three strains (ERR 492, ERR 494', and ERR 498) showed significantly higher NN than the others (Table 2). For NDM, the ERR 492, ERR 493, ERR 494 ${ }^{\top}$, ERR 498, ERR 496, ERR 497, ERR 569, and BR 6610 strains showed significant differences (Table 2). Of the 10 inoculated treatments, five treatments exhibited significant increases in RDM above $5.52 \mathrm{~g}$ per plant. The best result for RDM was achieved in the treatment with the ERR 496 strain, resulting in an increase of $6.68 \mathrm{~g}$ per plant, followed by the treatments with ERR 497, ERR 569, and BR 6610 and the Control $+\mathrm{N}$ treatment. For $\mathrm{PH}, \mathrm{SD}, \mathrm{NL}$, and SDM, there were no significant differences

Table 1. Inga edulis Mart. response to inoculation with Bradyrhizobium ingae strains under greenhouse conditions in pots with sterile substrate for 60 days (Experiment 1)

\begin{tabular}{|c|c|c|c|c|c|c|c|c|}
\hline Treatment & NN & NDM & RDM & PH & SD & NL & SDM & TN \\
\hline & no. & 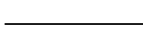 & 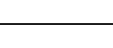 & $\mathrm{cm}$ & $\mathrm{mm}$ & no. & $g$ & $\mathrm{mg}$ \\
\hline ERR 490 & $367.67 \mathrm{a}$ & $656.0 \mathrm{a}$ & 2.44 & $32.00 \mathrm{~b}$ & $5.21 \mathrm{~b}$ & 37.67 & $6.09 a$ & $178.34 \mathrm{a}$ \\
\hline ERR 492 & $279.67 \mathrm{a}$ & $495.0 \mathrm{~b}$ & 2.81 & $36.33 \mathrm{a}$ & $6.43 \mathrm{a}$ & 37.00 & $6.11 \mathrm{a}$ & $181.11 \mathrm{a}$ \\
\hline ERR 493 & $296.67 \mathrm{a}$ & $492.4 \mathrm{~b}$ & 2.78 & $41.83 \mathrm{a}$ & $6.27 \mathrm{a}$ & 35.33 & $7.34 \mathrm{a}$ & $203.03 \mathrm{a}$ \\
\hline ERR $494^{\top}$ & $331.67 \mathrm{a}$ & $633.2 \mathrm{a}$ & 3.32 & $39.67 \mathrm{a}$ & $6.49 \mathrm{a}$ & 35.00 & $7.77 \mathrm{a}$ & $212.72 \mathrm{a}$ \\
\hline ERR 496 & $234.67 \mathrm{a}$ & $552.6 \mathrm{~b}$ & 2.60 & $39.67 \mathrm{a}$ & $5.36 \mathrm{~b}$ & 34.67 & $5.53 b$ & $194.29 a$ \\
\hline ERR 497 & $220.00 \mathrm{a}$ & $328.7 \mathrm{c}$ & 1.87 & $29.33 b$ & $5.64 \mathrm{~b}$ & 34.00 & $4.56 \mathrm{~b}$ & $153.54 \mathrm{a}$ \\
\hline ERR 498 & $337.00 \mathrm{a}$ & $507.3 b$ & 2.82 & $31.00 \mathrm{~b}$ & $5.76 \mathrm{~b}$ & 33.33 & $5.97 \mathrm{a}$ & $201.38 \mathrm{a}$ \\
\hline ERR 569 & $332.00 \mathrm{a}$ & $474.3 b$ & 2.67 & $35.67 \mathrm{a}$ & $7.14 \mathrm{a}$ & 32.33 & $6.90 \mathrm{a}$ & $214.32 \mathrm{a}$ \\
\hline BR 6609 & $279.00 \mathrm{a}$ & $690.7 a$ & 2.29 & $32.50 \mathrm{~b}$ & $5.81 \mathrm{~b}$ & 43.00 & $4.91 \mathrm{~b}$ & $161.12 \mathrm{a}$ \\
\hline BR 6610 & $144.67 \mathrm{a}$ & $443.1 b$ & 1.93 & $31.17 b$ & $5.00 \mathrm{~b}$ & 41.33 & $4.99 \mathrm{~b}$ & $150.83 a$ \\
\hline Control - $\mathrm{N}^{(1)}$ & 0.00 & 0.00 & 2.48 & $22.50 \mathrm{~b}$ & $4.49 \mathrm{~b}$ & 39.00 & $3.08 b$ & $45.48 \mathrm{~b}$ \\
\hline Control +N & 3.67 & 31.3 & 3.42 & $31.33 \mathrm{~b}$ & $5.91 \mathrm{~b}$ & 30.00 & $5.43 \mathrm{~b}$ & $139.90 \mathrm{a}$ \\
\hline CV (\%) & 21.8 & 2.62 & 18.69 & 16.73 & 12.09 & 15.4 & 18.03 & 22.78 \\
\hline
\end{tabular}

NN: number of nodules; NDM: nodule dry matter; RDM: root dry matter; PH: plant height; SD: stem diameter; NL: number of leaflets; SDM: shoot dry matter; TN: total $\mathrm{N}$ in the shoots. Values in the same column followed by the same letter were not significantly different according to the Scott-Knott test at $5 \%$ probability. ${ }^{(1)}$ The Control $-\mathrm{N}$ and Control $+\mathrm{N}$ treatments were not included in the statistical analyses for the NN and NDM variables. $\mathrm{CV}$ : coefficient of variation. 
among the treatments evaluated. For TN, the ERR 492, ERR 493, ERR $494^{\top}$, ERR 496, ERR 497, and ERR 498 strains showed significant differences. There were no significant differences in the RDM/SDM ratio and DQI (Figure 1 b). Eight strains showed RE values greater than 100 \% (ERR 492, ERR 493, ERR 494' ${ }^{\top}$, ERR 496, ERR 497, ERR 498, ERR 569, and BR 6609) (Figure 2).

\section{Experiment 3 - Symbiotic effectiveness in non-sterile substrate in a nursery}

The ERR 492, ERR 493, ERR 497, ERR 498, and ERR 569 strains showed significant differences in NN (Table 3). Almost all of the $B$. ingae strains, except for ERR 490, induced the production of a greater quantity of matter and showed significant differences for NDM. There were no significant differences for RDM and SD among the treatments. For PH, the ERR 492, ERR 493, ERR 496, ERR 497, ERR 498, ERR 569, BR 6610, and the Control $+\mathrm{N}$ treatment were significantly different. For NL, the ERR 493, ERR $494^{\top}$, ERR 498, and ERR 569 strains showed significantly higher values than the other remaining strains. The

(a)
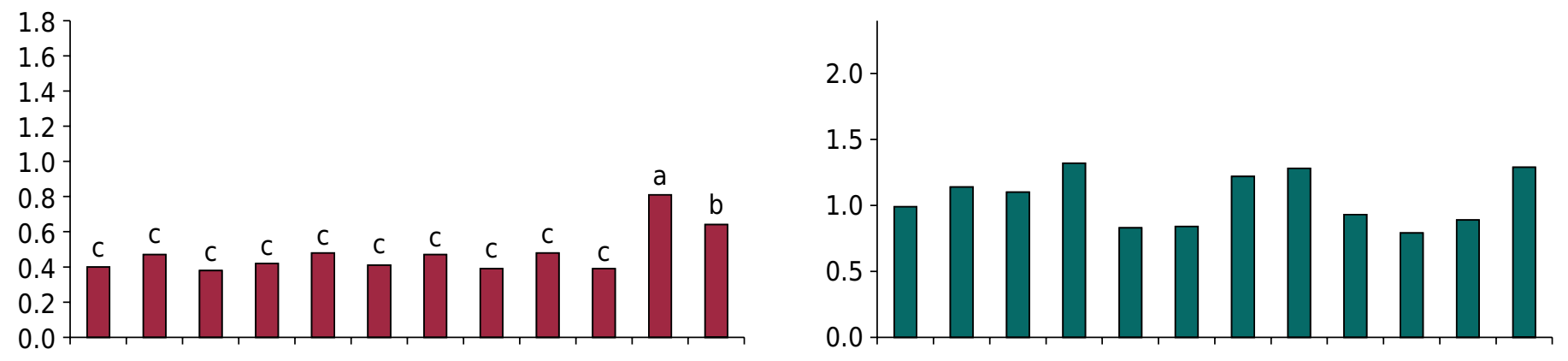

(b)
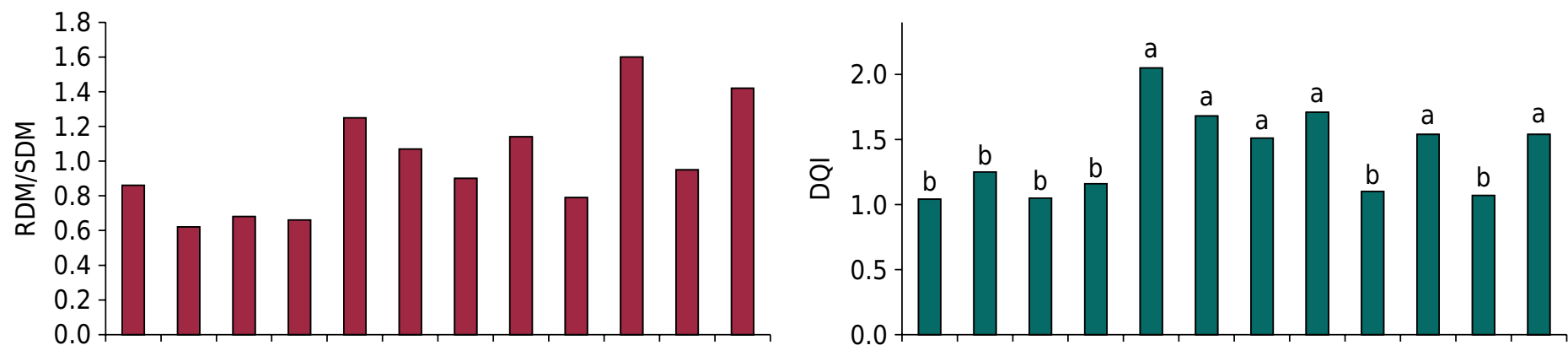

(c)
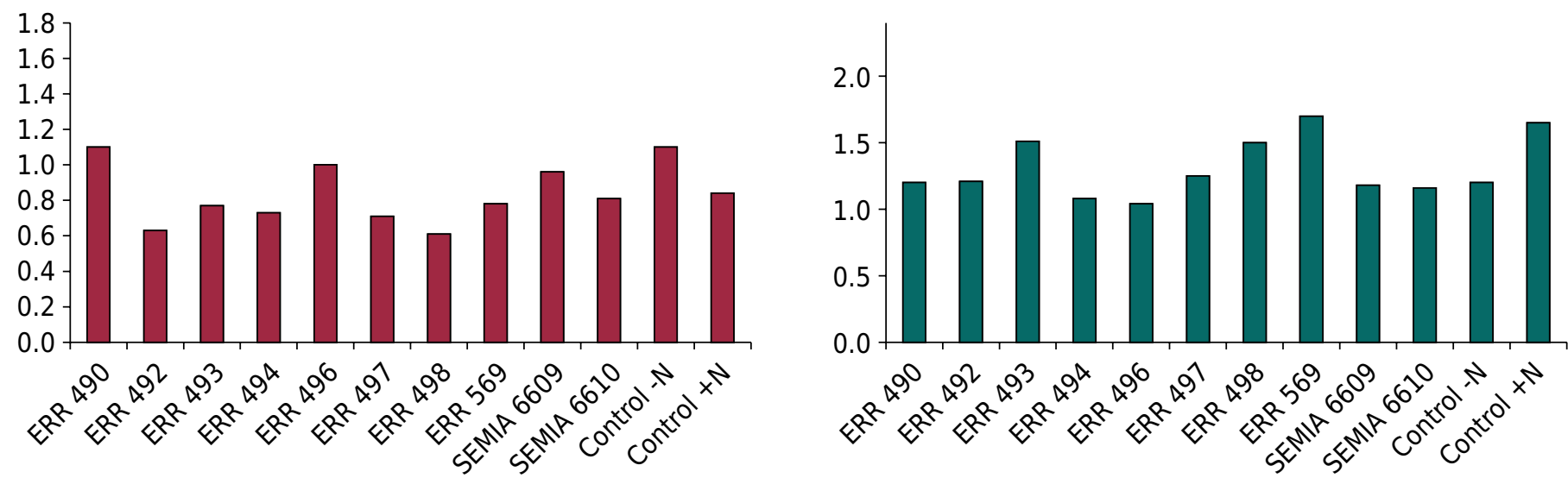

Figure 1. Effects of Bradyrhizobium ingae inoculation on the relationship of root/shoot dry matter ratio (RDM/SDM) and Dickson's quality index (DQI) of Inga edulis Mart. seedlings. (a) Experiment 1 - sterile substrate in a greenhouse; (b) Experiment 2 - non-sterile soil in a greenhouse; and (c) Experiment 3 - non-sterile substrate in a nursery. Values followed by the same letter were not significantly different according to the Scott-Knott test at $5 \%$ probability. 
ERR 492, ERR 493, ERR 497, ERR 498, and ERR 569 strains and the Control +N treatment exhibited significantly different values for SDM. A total of four strains (ERR 493, ERR 497, ERR 498, and ERR 569) showed significant differences for TN, with higher values than the Control $+\mathrm{N}$ treatment. There were no significant differences among the treatments for the RDM/SDM ratio and DQI (Figure 1c). Three strains (ERR 493, ERR 498, and ERR 569) showed RE values higher than $100 \%$ (Figure 2).

\section{Pearson's correlation ( $r$ )}

Pearson's correlations among the variables assessed in all the effectiveness experiments are presented in the table 4 . In the first experiment, the Pearson's correlation was positive and significant for NN with NDM, PH, SD, SDM, and TN; NDM with PH, SD, SDM, and TN; RDM with SD, SDM, and TN; PH with SD, SDM, and TN; SD with SDM and TN;

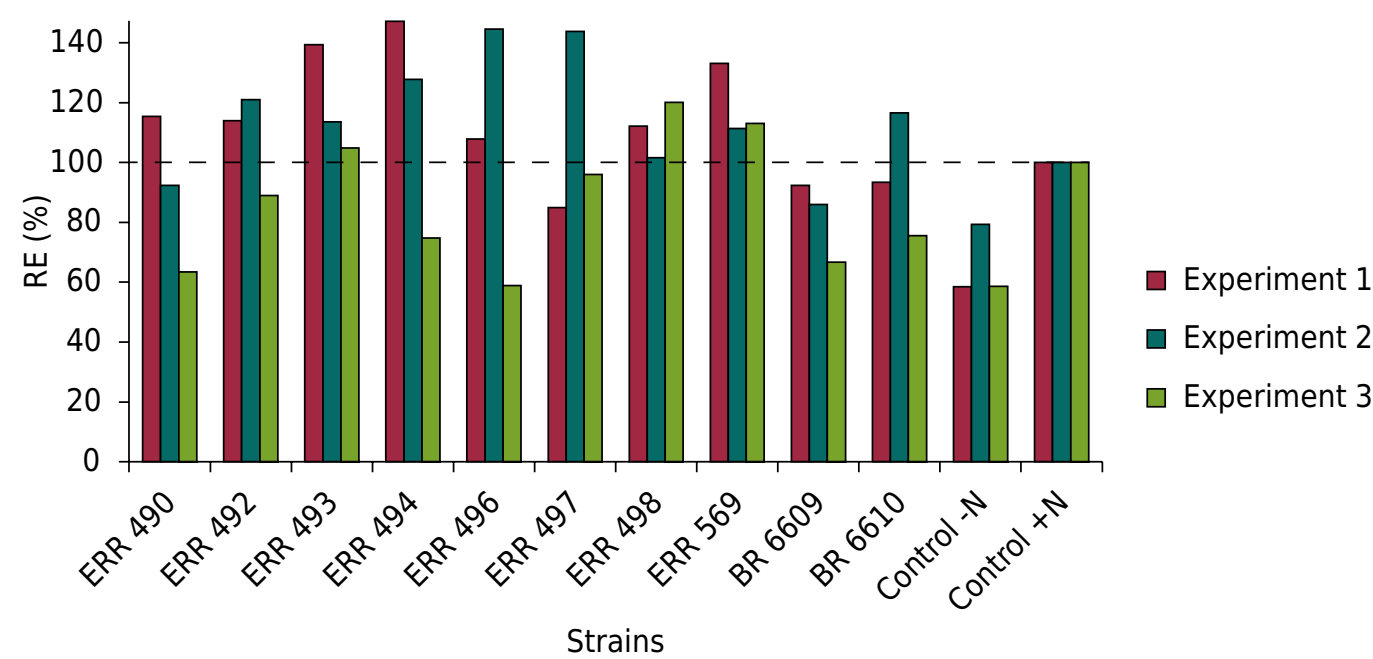

Figure 2. Relative effectiveness of Bradyrhizobium ingae strains inoculated in Inga edulis Mart. plants. Experiment 1 - sterile substrate in a greenhouse; Experiment 2 - non-sterile soil in a greenhouse; and Experiment 3 - non-sterile substrate in a nursery.

Table 2. Inga edulis Mart. response to inoculation with Bradyrhizobium ingae strains under greenhouse conditions in pots with non-sterile soil for 100 days (Experiment 2)

\begin{tabular}{|c|c|c|c|c|c|c|c|c|}
\hline Treatment & NN & NDM & RDM & PH & SD & NL & SDM & TN \\
\hline & no. & $\longrightarrow \mathrm{mg}$ & 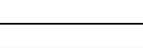 & $\mathrm{cm}$ & $\mathrm{mm}$ & no. & $g$ & $\mathrm{mg}$ \\
\hline ERR 490 & $15.75 \mathrm{c}$ & $57.05 \mathrm{~b}$ & $3.45 b$ & 29.13 & 4.97 & 34.25 & 3.92 & $74.6 \mathrm{~b}$ \\
\hline ERR 492 & $104.25 \mathrm{a}$ & $333.43 \mathrm{a}$ & $3.19 \mathrm{~b}$ & 26.00 & 4.70 & 33.75 & 5.67 & $168.7 \mathrm{a}$ \\
\hline ERR 493 & $56.75 \mathrm{~b}$ & $292.43 \mathrm{a}$ & $3.23 \mathrm{~b}$ & 30.50 & 4.82 & 32.75 & 4.81 & $127.0 \mathrm{a}$ \\
\hline ERR $494^{\top}$ & $91.50 \mathrm{a}$ & $372.03 \mathrm{a}$ & $3.60 \mathrm{~b}$ & 28.63 & 4.36 & 35.50 & 5.52 & $151.4 \mathrm{a}$ \\
\hline ERR 496 & $39.75 \mathrm{~b}$ & $285.85 \mathrm{a}$ & $6.68 a$ & 25.00 & 4.98 & 38.00 & 6.12 & $141.3 \mathrm{a}$ \\
\hline ERR 497 & $56.50 \mathrm{~b}$ & $389.41 \mathrm{a}$ & $5.70 \mathrm{a}$ & 26.25 & 4.53 & 50.00 & 5.87 & $146.6 \mathrm{a}$ \\
\hline ERR 498 & $86.50 \mathrm{a}$ & $401.15 \mathrm{a}$ & $4.19 \mathrm{~b}$ & 21.63 & 4.42 & 35.75 & 4.70 & $134.4 \mathrm{a}$ \\
\hline ERR 569 & $49.25 \mathrm{~b}$ & $246.28 \mathrm{a}$ & $5.60 a$ & 26.00 & 4.84 & 29.00 & 4.86 & $99.5 \mathrm{~b}$ \\
\hline BR 6609 & $31.50 \mathrm{~b}$ & $110.35 \mathrm{~b}$ & $3.20 \mathrm{~b}$ & 22.38 & 4.39 & 26.75 & 3.86 & $90.1 \mathrm{~b}$ \\
\hline BR 6610 & $39.25 \mathrm{~b}$ & $217.17 \mathrm{a}$ & $5.52 \mathrm{a}$ & 27.25 & 4.66 & 31.25 & 4.95 & $126.0 \mathrm{~b}$ \\
\hline Control -N & $2.50 \mathrm{c}$ & $7.55 \mathrm{~b}$ & $3.40 \mathrm{~b}$ & 23.75 & 4.26 & 25.00 & 3.52 & $71.3 \mathrm{~b}$ \\
\hline Control +N & $8.75 \mathrm{c}$ & $31.85 \mathrm{~b}$ & $6.34 a$ & 28.50 & 4.48 & 29.00 & 4.57 & $102.3 \mathrm{~b}$ \\
\hline CV (\%) & 12.38 & 5.43 & 37.06 & 17.03 & 8.64 & 12.73 & 28.86 & 7.12 \\
\hline
\end{tabular}

Number of nodules (NN), nodule dry matter (NDM), root dry matter (RDM), plant height (PH), stem diameter (SD), number of leaflets (NL), shoot dry matter (SDM), and total $\mathrm{N}$ in the shoots (TN). Values in the same column followed by the same letter were not significantly different according to the Scott-Knott test at $5 \%$ probability. CV: coefficient of variation. 
and SDM with TN. Significant correlations were found between the following variables in the second experiment: NN with NDM, SDM, and TN; NDM with RDM, SDM, and TN; RDM with NL, SDM, and TN; PH with SD and SDM; NL with RDM and SDM; and SDM with TN. In the third experiment, the following significant correlations were observed (Table 4): NN with NDM, PH, SD, NL, SDM, and TN; NDM with RDM, PH, SD, NL, SDM, and TN; RDM with SD, SDM, and TN; PH with SD, SDM, and TN; SD with NL, SDM, and TN; NL with SDM and TN; and SDM with TN.

\section{Phosphate solubilization}

Only two of the eight $B$. ingae strains showed a solubilization halo in solid media containing $\mathrm{CaHPO}_{4}$ (Table 5), ERR 490 and ERR 496, with a SI of 1.57 and 1.20, respectively, which are classified as low. Of the strains recommended for I. marginata, BR 6609 (Bradyrhizobium sp.) had a SI of 4.10 (high). The control strains BR $11175^{\top}$ (Herbaspirillum seropedicae) and BR $11001^{\top}$ (Azospirillum brasilense) had a SI of 3.23 and 2.18 (both medium), respectively (Table 5). None of the strains tested produced a solubilization halo in solid medium containing $\mathrm{AIPO}_{4}$. However, in liquid medium, four strains of $B$. ingae and Bradyrhizobium spp. were able to solubilize AIPO : ERR 490 (0.34 $\mathrm{mg} \mathrm{L}^{-1}$ of P), ERR 492 (0.06 $\mathrm{mg} \mathrm{L}^{-1}$ of P), ERR 493 (0.03 $\mathrm{mg} \mathrm{L}^{-1}$ of P), and BR 6609 ( $0.53 \mathrm{mg} \mathrm{L}^{-1}$ of $P$ ), corresponding to $2.83,0.5,0.25$, and $4.42 \%$ solubilization of the total $P$ added to the medium, respectively (Table 5). The BR $11001^{\top}$ and BR $11175^{\top}$ strains used as positive controls showed $6.25\left(0.75 \mathrm{mg} \mathrm{L}^{-1}\right.$ of $\mathrm{P}$ ) and $3.66 \%$ $\left(0.44 \mathrm{mg} \mathrm{L}^{-1}\right.$ of $\left.\mathrm{P}\right)$, respectively.

\section{Production of indole compounds}

Four of the eight $B$. ingae strains, ERR 490, ERR 492, ERR 493, and ERR $494^{\top}$, exhibited indole compound production in the presence of tryptophan, with production values ranging from 1.48 to $4.82 \mu \mathrm{g} \mathrm{mL}^{-1}$ (Table 5 ). In addition to the $B$. ingae strains, the BR 6610 strain was also capable of synthesizing $4.23 \mu \mathrm{g} \mathrm{mL}^{-1}$ of indole compounds, and the positive control, BR $11175^{\top}$, synthesized $2.50 \mu \mathrm{g} \mathrm{mL}^{-1}$. In the absence of tryptophan, three strains still exhibited this characteristic: ERR 492, ERR $494^{\top}$, and ERR 496 , with respective values of $5.77,7.57$, and $2.62 \mathrm{\mu g} \mathrm{mL}^{-1}$. Of the recommended

Table 3. Inga edulis Mart. response to inoculation with Bradyrhizobium ingae strains under nursery conditions in bags with non-sterile substrate for 100 days (Experiment 3)

\begin{tabular}{|c|c|c|c|c|c|c|c|c|}
\hline Treatment & NN & NDM & RDM & PH & SD & NL & SDM & TN \\
\hline & no. & $\longrightarrow$ & 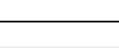 & $\mathrm{cm}$ & $\mathrm{mm}$ & no. & $g$ & $\mathrm{mg}$ \\
\hline ERR 490 & $16.00 \mathrm{c}$ & $84.73 b$ & 3.84 & $22.88 b$ & 4.89 & $24.75 b$ & $3.54 b$ & $74.9 \mathrm{~b}$ \\
\hline ERR 492 & $82.50 \mathrm{a}$ & $267.90 \mathrm{a}$ & 3.13 & $23.88 \mathrm{a}$ & 4.75 & $30.00 \mathrm{~b}$ & $4.94 \mathrm{a}$ & $141.0 \mathrm{~b}$ \\
\hline ERR 493 & $85.25 \mathrm{a}$ & $384.53 \mathrm{a}$ & 4.16 & $23.50 \mathrm{a}$ & 4.73 & $34.75 \mathrm{a}$ & $5.83 a$ & $173.0 \mathrm{a}$ \\
\hline ERR $494^{\top}$ & $44.75 \mathrm{~b}$ & $266.23 \mathrm{a}$ & 2.90 & $21.00 \mathrm{~b}$ & 4.60 & $36.50 \mathrm{a}$ & $4.17 \mathrm{~b}$ & $126.0 \mathrm{~b}$ \\
\hline ERR 496 & $60.00 \mathrm{~b}$ & 338.53 a & 3.21 & $24.13 a$ & 4.57 & $29.75 b$ & $3.30 \mathrm{~b}$ & $108.8 \mathrm{~b}$ \\
\hline ERR 497 & $74.50 \mathrm{a}$ & $326.53 \mathrm{a}$ & 3.71 & $25.25 a$ & 4.43 & $31.50 \mathrm{~b}$ & $5.40 \mathrm{a}$ & $173.0 \mathrm{a}$ \\
\hline ERR 498 & $97.25 \mathrm{a}$ & $320.75 a$ & 4.11 & $28.00 \mathrm{a}$ & 4.35 & $37.50 \mathrm{a}$ & $6.69 a$ & $199.5 \mathrm{a}$ \\
\hline ERR 569 & $97.75 \mathrm{a}$ & $430.73 a$ & 4.94 & $26.75 \mathrm{a}$ & 4.26 & $33.00 \mathrm{a}$ & $6.34 a$ & $222.7 \mathrm{a}$ \\
\hline BR 6609 & $6.00 \mathrm{c}$ & $142.88 \mathrm{~b}$ & 3.58 & $22.50 \mathrm{~b}$ & 4.12 & $30.00 \mathrm{~b}$ & $3.77 \mathrm{~b}$ & $81.9 \mathrm{~b}$ \\
\hline BR 6610 & $53.50 \mathrm{~b}$ & $203.03 \mathrm{~b}$ & 3.39 & $25.25 a$ & 4.03 & $35.75 \mathrm{a}$ & $4.18 \mathrm{~b}$ & $114.3 \mathrm{~b}$ \\
\hline Controle -N & $4.00 \mathrm{c}$ & $68.88 \mathrm{~b}$ & 3.51 & $19.50 \mathrm{~b}$ & 5.09 & $27.50 \mathrm{~b}$ & $3.26 \mathrm{~b}$ & $68.2 \mathrm{~b}$ \\
\hline Controle $+\mathrm{N}$ & $9.25 \mathrm{c}$ & $175.05 \mathrm{~b}$ & 4.78 & $25.25 \mathrm{a}$ & 4.90 & $42.00 \mathrm{a}$ & $5.63 a$ & $120.7 \mathrm{~b}$ \\
\hline CV (\%) & 22.51 & 31.48 & 28.64 & 10.57 & 10.59 & 9.12 & 24.32 & 28.96 \\
\hline
\end{tabular}

Number of nodules (NN), nodule dry matter (NDM), root dry matter (RDM), plant height (PH), stem diameter (SD), number of leaflets (NL), shoot dry matter (SDM), and total $\mathrm{N}$ in the shoots (TN). Values in the same column followed by the same letter were not significantly different according to the Scott-Knott test at $5 \%$ probability. CV: coefficient of variation. 
strains for I. marginata, only the BR 6609 strain was able to synthesize $2.30 \mu \mathrm{gLL}^{-1}$ of indole compounds in the absence of tryptophan (Table 5). The positive control strains BR $111175^{\top}$ and BR $11001^{\top}$ synthesized 49.02 and $3.94 \mu \mathrm{g} \mathrm{mL}{ }^{-1}$ of indole compounds, respectively.

\section{DISCUSSION}

In this study, the ability of strains of $B$. ingae, a recently-described species (Silva et al., 2014) for promoting growth in $I$. edulis seedlings, was investigated using three experiments: pots with sterile substrate in a greenhouse, pots with non-sterile soil in a greenhouse, and non-sterile substrate in a nursery setting. Generally, nodules were present on the plants 45 days after sowing in all experiments. These observations differ from those found in other species belonging to the genus Inga. For example, I. oerstediana and I. jinicuil exhibited nodulation at 150 and 130 days after sowing, respectively (van Kessel and Roskoski, 1983; Grossman et al., 2006). The rapid establishment of symbiosis between plant and bacteria might be due to the rapid growth of $I$. edulis, which is a desirable characteristic for use in agroforestry systems. It is also noteworthy that $I$. edulis is a plant adapted to acidic soils with low fertility (Hands, 1998), which are common properties of savanna soils of Roraima (Benedetti et al., 2011). Moreover, inoculation with native strains that are adapted to these soils could have promoted the rapid development of

Table 4. Matrix of Pearson correlation ( $r$ ) of variables utilized in the three experiments of symbiotic effectiveness of Bradyrhizobium ingae inoculated in Inga edulis Mart. seedlings

\begin{tabular}{|c|c|c|c|c|c|c|c|c|}
\hline & NN & NDM & RDM & PH & SD & NL & SDM & TN \\
\hline \multirow[t]{3}{*}{ NN } & 1.00 & & & & & & & \\
\hline & 1.00 & & & & & & & \\
\hline & 1.00 & & & & & & & \\
\hline \multirow[t]{3}{*}{ NDM } & $0.75^{* * *}$ & 1.00 & & & & & & \\
\hline & $0.79 * * *$ & 1.00 & & & & & & \\
\hline & $0.70 * * *$ & 1.00 & & & & & & \\
\hline \multirow[t]{3}{*}{ RDM } & $0.33 \mathrm{~ns}$ & $0.25 \mathrm{~ns}$ & 1.00 & & & & & \\
\hline & $-0.13^{* * *}$ & $0.14 * * *$ & 1.00 & & & & & \\
\hline & $0.27 n s$ & $0.39 * *$ & 1.00 & & & & & \\
\hline \multirow[t]{3}{*}{$\mathrm{PH}$} & $0.45^{* *}$ & $0.52^{* *}$ & $0.30 \mathrm{~ns}$ & 1.00 & & & & \\
\hline & $0.20 \mathrm{~ns}$ & $0.08 n s$ & $-0.03 n s$ & 1.00 & & & & \\
\hline & $0.51^{* * *}$ & $0.36 *$ & $0.17 \mathrm{~ns}$ & 1.00 & & & & \\
\hline \multirow[t]{3}{*}{ SD } & $0.62 * * *$ & $0.41 *$ & $0.53^{* *}$ & $0.59 * * *$ & 1.00 & & & \\
\hline & $-0.03 n s$ & $0.11 \mathrm{~ns}$ & $0.21 \mathrm{~ns}$ & $0.37 *$ & 1.00 & & & \\
\hline & $0.39 * *$ & $0.30 *$ & $0.33^{*}$ & $0.56 * * *$ & 1.00 & & & \\
\hline \multirow[t]{3}{*}{ NL } & $0.11 \mathrm{~ns}$ & $0.01 \mathrm{~ns}$ & $0.00 \mathrm{~ns}$ & $-0.16 n s$ & $0.05 n s$ & 1.00 & & \\
\hline & $0.17 \mathrm{~ns}$ & $0.25 \mathrm{~ns}$ & $0.12^{* * *}$ & $0.17 \mathrm{~ns}$ & $0.26 \mathrm{~ns}$ & 1.00 & & \\
\hline & $0.34 *$ & $0.31 *$ & $0.16 \mathrm{~ns}$ & $0.14 \mathrm{~ns}$ & $0.35 *$ & 1.00 & & \\
\hline \multirow[t]{3}{*}{ SDM } & $0.74 * * *$ & $0.63^{* * *}$ & $0.64 * * *$ & $0.76^{* * *}$ & $0.75^{* * *}$ & $-0.02 n s$ & 1.00 & \\
\hline & $0.52^{* * *}$ & $0.70 * * *$ & $0.23^{* * *}$ & $0.14^{* *}$ & $0.21 \mathrm{~ns}$ & $0.36^{* * *}$ & 1.00 & \\
\hline & $0.69 * * *$ & $0.67^{* * *}$ & $0.50 * * *$ & $0.46 * *$ & $0.43^{* *}$ & $0.43^{* *}$ & 1.00 & \\
\hline \multirow[t]{3}{*}{ TN } & $0.69 * * *$ & $0.67^{* * *}$ & $0.37 *$ & $0.68^{* * *}$ & $0.72 * * *$ & $0.10 \mathrm{~ns}$ & $0.78^{* * *}$ & 1.00 \\
\hline & $0.63^{* * *}$ & $0.75^{* * *}$ & $-0.04 * * *$ & $0.13 \mathrm{~ns}$ & $0.05 \mathrm{~ns}$ & $0.26 \mathrm{~ns}$ & $0.83^{* * *}$ & 1.00 \\
\hline & $0.75^{* * *}$ & $0.71^{* * *}$ & $0.43^{* *}$ & $0.49 * * *$ & $0.45^{* *}$ & $0.43^{* *}$ & $0.92 * * *$ & 1.00 \\
\hline
\end{tabular}

Number of nodules (NN), nodule dry matter (NDM), root dry matter (RDM), plant height (PH), stem diameter (SD), number of leaflets (NL), shoot dry matter (SDM), and total $\mathrm{N}$ in the shoots (TN). Correlation coefficients: the first line is for Experiment 1 - sterile substrate in a greenhouse; the second line, Experiment 2 - non-sterile soil in a greenhouse; and the third line, Experiment 3 - non-sterile substrate in a nursery. ${ }^{*}, * *$ and $* * *$ : statistical significance at $\rho<0.05 ; \rho<0.01$ and $\rho<0.001$, respectively; ns: not significant. 
symbiosis. Differences in symbiotic effectiveness between inoculated and uninoculated treatments were observed later in the experimental cycle, at 60 days for sterile conditions and 100 days for non-sterile conditions, when the experiments were collected.

After conducting these three experiments, it was observed that $B$. ingae strains were effective in promoting $I$. edulis seedling development in both sterile and non-sterile substrates (Tables 1, 2, and 3). It was verified that NN was higher in sterile substrate (Table 1). Values for NDM obtained in sterile substrate were also higher than those obtained in non-sterile substrates. The decreases in NN and NDM in non-sterile conditions could be due to the presence, even if in low amounts, of organic matter and, consequently, $\mathrm{N}$ in the soil. Furthermore, competition between bacteria and other native microorganisms in the soil may reduce the bacterial population present in the inoculant. Thus, during the process of selecting bacteria for the inoculation of legume plants, after determining the strains which are effective in $\mathrm{N}$-fixing under sterile conditions, it also becomes necessary to evaluate their competition with native bacteria in non-sterile soils (Stowers and Elkan, 1980; Franco and Faria, 1997). In some variables, although there were increases in RDM, $\mathrm{PH}, \mathrm{SD}$, and $\mathrm{NL}$ when plants were inoculated with bacterial strains, these differences were not significant in all of the experiments. The lack of significant differences for some variables in different experiments might be correlated with genetic variability in the native tree species. However, there were significant differences for NN, NDM, SDM, and TN. SDM did not exhibit significant differences in pots filled with non-sterile soils, but there was an increase due to inoculation. For example, inoculation with the ERR 496 strain led to the production of $6.12 \mathrm{~g}$ of SDM, whereas $3.52 \mathrm{~g}$ was produced in the Control $-\mathrm{N}$ treatment (Table 2).

For the RDM/SDM ratio, there were only significant differences in the first experiment conducted in pots with sterile substrate (Figure 1a). In this case, the Control - $\mathrm{N}$ treatment had the highest value, followed by the Control $+\mathrm{N}$ treatment. The RDM/SDM ratio is one of the parameters used to assess the stability of forest seedlings, and very small values can compromise the establishment of seedlings in the field (Ferraz and Engel, 2011). However, this ratio must be evaluated with caution in inoculation experiments because the Control $-\mathrm{N}$ treatment (without inoculation and without $\mathrm{N}$ ) has reduced shoot development, resulting in a higher value for the RDM/SDM ratio. The DQI (Table 1) must also be

Table 5. Phosphate solubilization and production of indole compounds by Bradyrhizobium ingae strains

\begin{tabular}{|c|c|c|c|c|c|c|}
\hline \multirow{2}{*}{ Strain } & \multirow{2}{*}{$\frac{\mathrm{CaHPO}_{4} \text { solubilization }}{\text { SI }}$} & \multicolumn{3}{|c|}{$\mathrm{AIPO}_{4}$ solubilization } & \multicolumn{2}{|c|}{ Production of indole compounds } \\
\hline & & Soluble P & pH & $\%$ of soluble $\mathbf{P}$ & Trp+ & Trp- \\
\hline & & $\mathrm{mg} \mathrm{L}^{-1}$ & & & 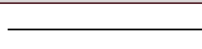 & 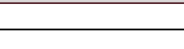 \\
\hline ERR 490 & 1.57 (low) & 0.34 & 3.85 & 2.83 & $2.48 \mathrm{~b}$ & - \\
\hline ERR 492 & - & 0.06 & 4.20 & 0.50 & $4.82 \mathrm{a}$ & $5.77 \mathrm{~b}$ \\
\hline ERR 493 & - & 0.03 & 4.27 & 0.25 & $2.55 \mathrm{~b}$ & - \\
\hline ERR $494^{\top}$ & - & 0 & & 0 & $1.48 \mathrm{~b}$ & $7.57 \mathrm{~b}$ \\
\hline ERR 496 & 1.20 (low) & 0 & & 0 & - & $2.62 c$ \\
\hline ERR 497 & - & 0 & & 0 & - & - \\
\hline ERR 498 & - & 0 & & 0 & - & - \\
\hline ERR 569 & - & 0 & & 0 & - & - \\
\hline BR 6609 & 4.10 (high) & 0.53 & 3.78 & 4.42 & - & $2.30 \mathrm{c}$ \\
\hline BR 6610 & - & 0 & & 0 & $4.23 \mathrm{a}$ & - \\
\hline BR $11175^{\top}$ & 3.23 (medium) & 0.44 & 4.22 & 3.66 & $2.50 \mathrm{~b}$ & $49.02 \mathrm{a}$ \\
\hline BR $11001^{\top}$ & 2.18 (medium) & 0.75 & 3.48 & 6.25 & - & $3.94 \mathrm{c}$ \\
\hline CV (\%) & - & 28.09 & - & & 13.68 & 35.03 \\
\hline
\end{tabular}

SI: solubilization index, low $(\mathrm{SI}<2)$, medium $(2 \leq \mathrm{SI}<4)$ or high $(\mathrm{SI}>4)$. Means followed by the same letter were not significantly different according to the Scott- Knott test at $5 \%$ probability. CV: coefficient of variation. 
evaluated with caution because there are no reference values for quality in the literature for different native tree species (Ferraz and Engel, 2011), which hinders analysis of the DQI. However, the values found in this study for the three experiments were higher than those presented by Góes et al. (2015) for I. laurina seedlings. Those authors obtained DQI values ranging from 0.36 to 0.43 after inoculation with $\mathrm{N}$-fixing bacteria, whereas they obtained a value of 0.97 for the treatment that received $\mathrm{N}$ fertilizer. These results indicate that $B$. ingae strains were effective in promoting $I$. edulis seedling development because they did not produce results different from the Control $+\mathrm{N}$ treatment.

Variation in the RE of $B$. ingae strains was detected in our study. Three of these strains (ERR 493, ERR 498, and ERR 569) had values higher than $100 \%$ in all three experiments (Figure 1), indicating that these strains were capable of effectively supplying $\mathrm{N}$ to the plants. Few studies have calculated the RE in leguminous trees. For example, Marques et al. (2001) found an RE of $56.4 \%$ for the combined inoculation of rhizobia strains and mycorrhizal fungi in Centrolobium tomentosum. In a study of $I$. oerstediana conducted by Grossman et al. (2006), none of their investigated strains exhibited RE over $100 \%$; all of the strains showed lower biomass production compared to the treatments with $\mathrm{N}$ and without inoculation in both non-sterile and sterile conditions. However, the BR 6609 and BR 6610 strains exhibited RE of $81 \%$ when evaluated under sterile conditions after inoculation of $I$. marginata (Franco and Faria, 1997). Currently, these two strains are recommended for inoculation of this species (Brasil, 2011). Therefore, $B$. ingae strains also have potential to be recommended for inoculation of $I$. edulis seedlings.

Correlation analysis of the variables utilized in all of the three experiments of symbiotic effectiveness (Table 4) showed that NDM, NN, SDM, and TN had the highest values and were significant, with positive correlations with the other variables. In this sense, these variables must be considered for evaluation of the effectiveness of $\mathrm{N}$-fixing bacteria in Inga plants. Although NN showed a positive correlation with several of the variables studied, NDM should be used for selection purposes (Norris and Date, 1976) because ineffective or inactive nodules can form, resulting in a higher number of nodules but with low effectiveness. Nodule dry matter has a direct correlation with plant dry matter production and N concentration (Döbereiner, 1966; Stowers and Elkan, 1980). This observation was confirmed in the three experiments, with values higher than 0.60 (Table 4). The variables total $\mathrm{N}$ and total dry matter production are important for the selection of high-performing strains for biological $\mathrm{N}$ fixation in legumes. Therefore, the use of bacterial strains effective in biological fixation results in increased $\mathrm{N}$ content and, consequently, increased shoot development and is an alternative for improving soil fertility. Plants of the genus Inga have been used to provide $\mathrm{N}$ to recover degraded areas and also in agroforestry systems (Grossman et al., 2006). Inga spp. have also been used to provide shade on coffee bean farms in Mexico. In addition to providing shade, the use of I. jinicuil was found to be a good source of $\mathrm{N}$ input in this production system (Roskoski, 1981). After evaluating the results obtained in this study, three strains, ERR 493, ERR 498, and ERR 569, were selected as being the most effective in biological $\mathrm{N}$ fixation in I. edulis. These strains stood out for their TN contents and, as a consequence, higher SDM production, and RE values that were greater than $100 \%$.

It is advantageous that the selected strains also have other mechanisms for promoting plant growth not limited to biological $\mathrm{N}$ fixation, because they can contribute to the production of higher quality seedlings. Thus, their $\mathrm{CaHPO}_{4}$ and $\mathrm{AlPO}_{4}$ solubilization abilities and their ability to produce indole compounds were evaluated. It was observed that $B$. ingae strains were able to solubilize $\mathrm{CaHPO}_{4}$ in solid medium and $\mathrm{AlPO}_{4}$ in liquid medium. The formation of a solubilization halo was not detected in solid medium containing AlPO$_{4}$. This result differed from other $\mathrm{AlPO}_{4}$ solubilization studies in which several authors detected solubilization halos in solid media containing P precipitated with Al (Hara and Oliveira, 2005; Marra et al., 2011, 2012; Oliveira-Longatti et al., 2014). However, it is important to note that the media and the sources of $\mathrm{P}$ were different from these studies. Such 
differences might explain the absence of a solubilization halo in the $B$. ingae strains tested. The absence of a solubilization halo in solid media cannot be used as the only criterion in selecting solubilizing organisms, mainly because bacteria can solubilize phosphates (Ca, Al, or Fe) without forming a visible solubilization halo (Bashan et al., 2013). These results are in agreement with Souchie et al. (2005), who detected a low incidence of Al-solubilizing organisms in solid media but observed that all the strains were capable of solubilizing $\mathrm{AlPO}_{4}$ in liquid media. In this sense, available $\mathrm{P}$ must also be quantified. Although there was no halo formation in solid media, three $B$. ingae strains (ERR 490, ERR 492, and ERR 493) were capable of solubilizing $\mathrm{AIPO}_{4}$ in liquid media (Table 5).

The $B$. ingae strains were also capable of producing indole compounds with or without tryptophan (Table 5). The results obtained for synthesis of indole compounds by $B$. ingae strains were similar to results found for other Bradyrhizobium spp. native to the Amazon, with maximum values of $10 \mathrm{mg} \mathrm{mL}^{-1}$ (Oliveira-Longatti et al., 2014). Of the $B$. ingae strains, ERR $494^{\top}$ and ERR 492 exhibited significant amounts in a tryptophan-independent pathway. It is highly advantageous to select bacteria that can synthesize indole compounds via tryptophan-independent pathways because the amino acid content of soils is generally low.

Biological $\mathrm{N}$ fixation by Bradyrhizobium is well documented. However, some studies have reported that the strains belonging to this genus share characteristics of plant growth-promoting rhizobacteria, such as phytohormone production, phosphate solubilization, and production of siderophores (Antoun et al., 1998; Boiero et al., 2007; Oliveira-Longatti et al., 2014). B. ingae strains showed plant growth-promoting mechanisms that may improve the development of Inga seedlings; they could also be tested as growth promoters on non-legumes. The most effective strains for biological $\mathrm{N}$ fixation were ERR 493, ERR 498, and ERR 569. In addition to its strong N-fixation ability, the ERR 493 strain was able to solubilize $\mathrm{AlPO}_{4}$ and produce indole compounds in the absence of tryptophan. Thus, this particular strain has great potential for promoting the growth and development of $I$. edulis seedlings. Such characteristics are extremely important for the production of high-quality seedlings of leguminous trees because they aid in the survival of these seedlings after transplanting in the field.

\section{CONCLUSIONS}

The Bradyrhizobium ingae strains evaluated in this study were able to effectively nodulate Inga edulis Mart. plants.

The ERR493, ERR 498, and ERR 569 strains were most effective in biological N fixation.

In addition to biological $\mathrm{N}$ fixation, $B$. ingae strains have other mechanisms that promote plant growth, such as their abilities to solubilize calcium and aluminum phosphates and synthesize indole compounds.

Bradyrhizobium ingae strains can be used as an inoculant during I. edulis seedling production.

\section{REFERENCES}

Antoun H, Beauchamp CJ, Goussard N, Chabot R, Lalande R. Potential of Rhizobium and Bradyrhizobium species as plant growth promoting rhizobacteria on non-legumes: Effect on radishes (Raphanus sativus L.). Plant Soil. 1998;204:57-67. doi:10.1023/A:1004326910584

Bashan Y, Kamnev AA, De-Bashan LE. Tricalcium phosphate is inappropriate as a universal selection factor for isolating and testing phosphate-solubilizing bacteria that enhance plant growth: a proposal for an alternative procedure. Biol Fertil Soils. 2013;49:465-79. doi:10.1007/s00374-012-0737-7

Benedetti UG, Vale Júnior JF, Schaefer CE, Melo VF, Uchôa SCP. Gênese, química e mineralogia de solos derivados de sedimentos pliopleistocênicos e de rochas vulcânicas básicas em Roraima, Norte Amazônico. Rev Bras Cienc Solo. 2011;35:299-312. doi:10.1590/S0100-06832011000200002 
Bergensen FJ, Brockwell J, Gibson AH, Schwinghamer EA. Studies of natural populations and mutants of Rhizobium in the improvement of legume inoculants. Plant Soil. 1971;46:3-16. doi:10.1007/BF02661831

Berraquero FR, Baya AM, Cormenzana AR. Establecimiento de índices para el estudio de la solubilización de fosfatos por bacterias del suelo. Ars Pharm. 1976;17:399-406.

Boiero L, Perrig D, Masciarelli O, Penna C, Cassán F, Luna V. Phytohormone production by three strains of Bradyrhizobium japonicum and technological implications. Appl Microbiol Biotechnol. 2007;74:874-80. doi:10.1007/s00253-006-0731-9

Brasil. Ministério da Agricultura, Pecuária e Abastecimento. Instrução Normativa no 13, de 24 de março de 2011. [internet]. Brasília, DF: Disponível em: http://sistemasweb.agricultura.gov.br/ sislegis/action/detalhaAto.do?method =gravarAtoPDF\&tipo $=I N M \&$ numeroAto $=00000013 \&$ seqAt $0=000 \&$ valorAno $=2011 \&$ orgao $=$ SDA/MAPA $\&$ codTipo $=\&$ desltem $=\&$ desitemFim $=$.

Dickson A, Leaf AL, Hosner JF. Quality appraisal of white spruce and white pine seedling stock in nurseries. For Chron. 1960;36:10-3. doi:10.5558/tfc36010-1

Döbereiner J. Evaluation of nitrogen fixation in legumes by the regression of total plant nitrogen with nodule weight. Nature. 1966;21:850-2. doi:10.1038/210850a0

Empresa Brasileira de Pesquisa Agropecuária - Embrapa. Manual de análises químicas de solos, plantas e fertilizantes. 2a ed. Brasília, DF: Embrapa Informação Tecnológica; 2009.

Ferraz AV, Engel VL. Efeito do tamanho de tubetes na qualidade de mudas de jatobá (Hymenaea courbaril L. var. stilbocarpa (Hayne) Lee et Lang.), ipê-amarelo (Tabebuia chrysotricha (Mart. Ex. DC.) Sandl.) e guarucaia (Parapiptadenia rigida (Benth.) Brenan). Rev Árvore. 2011;35:413-23. doi:10.1590/S0100-67622011000300005

Ferreira EB, Cavalcanti PP, Nogueira DA. ExpDes: Experimental designs package. R package version 1.1.2.. 2013. Available at: http://CRAN.R-project.org/package=ExpDes.

Franco AA, Faria SM. The contribution of $\mathrm{N}_{2}$ fixing tree legumes to land reclamation and sustainability in the tropics. Soil Biol Biochem. 1997;29:897-903. doi:10.1016/S0038-0717(96)00229-5

Fred EB, Waksman S. Laboratory manual of general microbiology. New York: McGraw-Hill; 1928.

Garcia FCP, Fernandes JM. Inga in lista de espécies da flora do Brasil. Rio de Janeiro: Jardim Botânico do Rio de Janeiro; 2015. [acesso: 10 Jan. 2016]. Disponível em: http://floradobrasil.jbrj. gov/br/jabot/floradobrasil/FB22803.

Góes GS, Gross E, Brito-Rocha E, Mielke MS. Efeito da inoculação com bactérias diazotróficas e da adubação nitrogenada no crescimento e na qualidade de mudas de Inga laurina (SW.) Willd. (Fabaceae). Rev Árvore. 2015;39:1031-8. doi:10.1590/0100-67622015000600005

Grossman JM, Sheaffer C, Wyse D, Bucciarelli B, Vance C, Graham PH. An assessment of nodulation and nitrogen fixation in inoculated Inga oerstediana, a nitrogen fixing tree shading organically grown coffee in Chiapas, Mexico. Soil Biol Biochem. 2006;38:769-84. doi:10.1016/j.soilbio.2005.07.009

Guimarães AA, Jaramillo PMD, Nóbrega RSA, Florentino LA, Silva KB, Moreira FMS. Genetic and symbiotic diversity of nitrogen-fixing bacteria isolated from agricultural soils in the Western Amazon by using cowpea as the trap plant. Appl Environ Microbiol. 2012;78:6726-33. doi:10.1128/AEM.01303-12

Hands MR. The uses of Inga in the acid soils of the Rainforest zone: Alley-cropping sustainability and soil-regeneration. In: Pennington TD, Fernandes ECM, editors. The Genus Inga: Utilization. Kew: The Royal Botanic Gardens; 1998. p.53-86.

Hara FAS, Oliveira LA. Características fisiológicas e ecológicas de isolados de rizóbios oriundos de solos ácidos e álicos de Iranduba, Amazonas. Pesq Agropec Bras. 2005;40:667-72. doi:10.1590/S0100-204X2005000700007

Hoagland DR, Arnon DI. The water-culture method for growing plants without soil. Berkeley: University of California; 1950. (California Agricultural Experiment Station Circular, 347).

Kuss AV, Kuss VV, Lovato T, Flôres ML. Fixação de nitrogênio e produção de ácido indolacético in vitro por bactérias diazotróficas endofíticas. Pesq Agropec Bras. 2007;42:1459-65.

doi:10.1590/S0100-204X2007001000013 
Leblanc HA, Nigren P, Mcgraw RL. Green mulch decomposition and nitrogen release from leaves of two Inga spp. in an organic alley - cropping practice in the humid tropics. Soil Biol Biochem. 2006;38:349-58. doi:10.1016/j.soilbio.2005.05.012

Marques MS, Pagano M, Scotti MRMML. Dual inoculation of a woody legume (Centrolobium tomentosum) with rhizobia and mycorrhizal fungi in South-eastern Brasil. Agrofor Syst. 2001;52:107-17. doi:10.1023/A:1010637401475

Marra LM, Oliveira SM, Soares FSCR, Moreira FMS. Solubilization of inorganic phosphates by inoculant strains from tropical legumes. Sci Agric. 2011;68:603-9. doi:10.1590/S0103-90162011000500015

Marra LM, Soares FSCR, Oliveira SM, Ferreira PAA, Soares BL, Carvalho RF, Lima JM, Moreira FMS. Biological nitrogen fixation and phosphate solubilization by bacteria isolated from tropical soils. Plant Soil. 2012;353:289-307. doi:10.1007/s11104-012-1157-z

Nautiyal CS. An effective microbiological growth medium for screening phosphate solubilizing microorganisms. FEMS Microbiol Lett. 1999;170:265-70. doi:10.1111/j.1574-6968.1999.tb13383.x

Nichols JD, Rosemeyer ME, Carpenter FL, Kettler J. Intercropping legume trees with native timber trees rapidly restores cover to eroded tropical pasture without fertilization. For Ecol Manage. 2001;52:195-209. doi:10.1016/S0378-1127(00)00603-4

Norris DO, Date RA. Legume bacteriology. In: Shaw NH, Bryan WW, editors. Tropical pasture research - principles and methods. Brisbane: CAB; 1976. p.134-74.

Oliveira-Longatti SM, Marra LM, Soares BL, Bomfeti CA, Silva K, Ferreira PAA, Moreira FMS. Bacteria isolated from soils of the western Amazon and from rehabilitated bauxite-mining areas have potential as plant growth promoters. World J Microbiol Biotechnol. 2014;30:1239-50. doi:10.1007/s11274-013-1547-2

Pennington TD. The genus Inga: Botany. Kew: The Royal Botanic Gardens; 1997.

Possette RFS, Rodrigues WA. O genêro Inga Mill. (Leguminosae - Mimosoideae) no estado do Paraná, Brasil. Acta Bot Bras. 2010;24:354-68. doi:10.1590/S0102-33062010000200006

R Core Team. R: A language and environment for statistical computing. [internet]. Vienna: R Foundation for Statistical Computing; 2013 [accessed on: 10 Nov. 2015]. Available at: http://www.R-project.org/.

Roskoski J. Nodulation and $\mathrm{N}_{2}$-fixation by Inga jinicuil, a woody legume in coffee plantations. I. Measurements of nodule biomass and field $\mathrm{C}_{2} \mathrm{H}_{2}$ reduction rates. Plant Soil. 1981;59:201-6.

Sarwar M, Kremer RJ. Determination of bacterially derived auxins using a microplate method. Lett Appl Microbiol. 1995;20:282-5. doi:10.1111/j.1472-765X.1995.tb00446.x

Scott AJ, Knott MA. Cluster analysis method for grouping means in the analysis of variance. Biometrics. 1974;30:507-12. doi:10.2307/2529204

Silva K, De Meyer S, Rouws LFM, Farias ENC, Santos MAO, O'Hara G, Ardley JK, Willems A, Pitard RM, Zilli JE. Bradyrhizobium ingae sp. nov., isolated from effective nodules of Inga laurina grown in Cerrado soil. Int J Syst Evol Microbiol. 2014;64:3395-401. doi:10.1099/ijs.0.063727-0

Souchie EL, Campello EFC, Saggin-Júnior OJ, Silva EMR. Mudas de espécies arboreas inoculadas com bactérias solubilizadoras de fosfato e fungos micorrízicos arbusculares. Floresta. 2005;35:329-34

Souza JS, Bastos MNC, Gurgel ESC. O gênero Ingá (Leguminosae-Mimosoideae) na Província Petrolífera de Urucu, Coari, Amazonas, Brasil. Rodriguesia. 2011;2:283-97.

Stowers MD, Elkan GH. Criteria for selecting infective and effective strains of Rhizobium for use in tropical agriculture. Durham: North Carolina Central University; 1980. (Technical Bulletin, 264).

van Kessel C, Roskoski JP. Nodulation and $\mathrm{N}_{2}$ fixation by Inga jinicuil, a woody legume in coffee plantations. III. Effect of fertilizers and soil shading on nodulation and nitrogen fixation (acetylene reduction) of I. jinicuil seedlings. Plant Soil. 1983;72:95-105. doi:10.1007/BF02185099

Vincent JM. A manual for the practical study of root nodule bacteria. Oxford: Blackwell Scientific Publications; 1970. 